\title{
Peran Guru dalam Pengajaran Pendidikan Multikultural: Inisiasi dan Praktek
}

\author{
Munaya Ulil Ilmi, Indah Mayangsari, Fisca Artita Dewi
}

Universitas Ahmad Dahlan

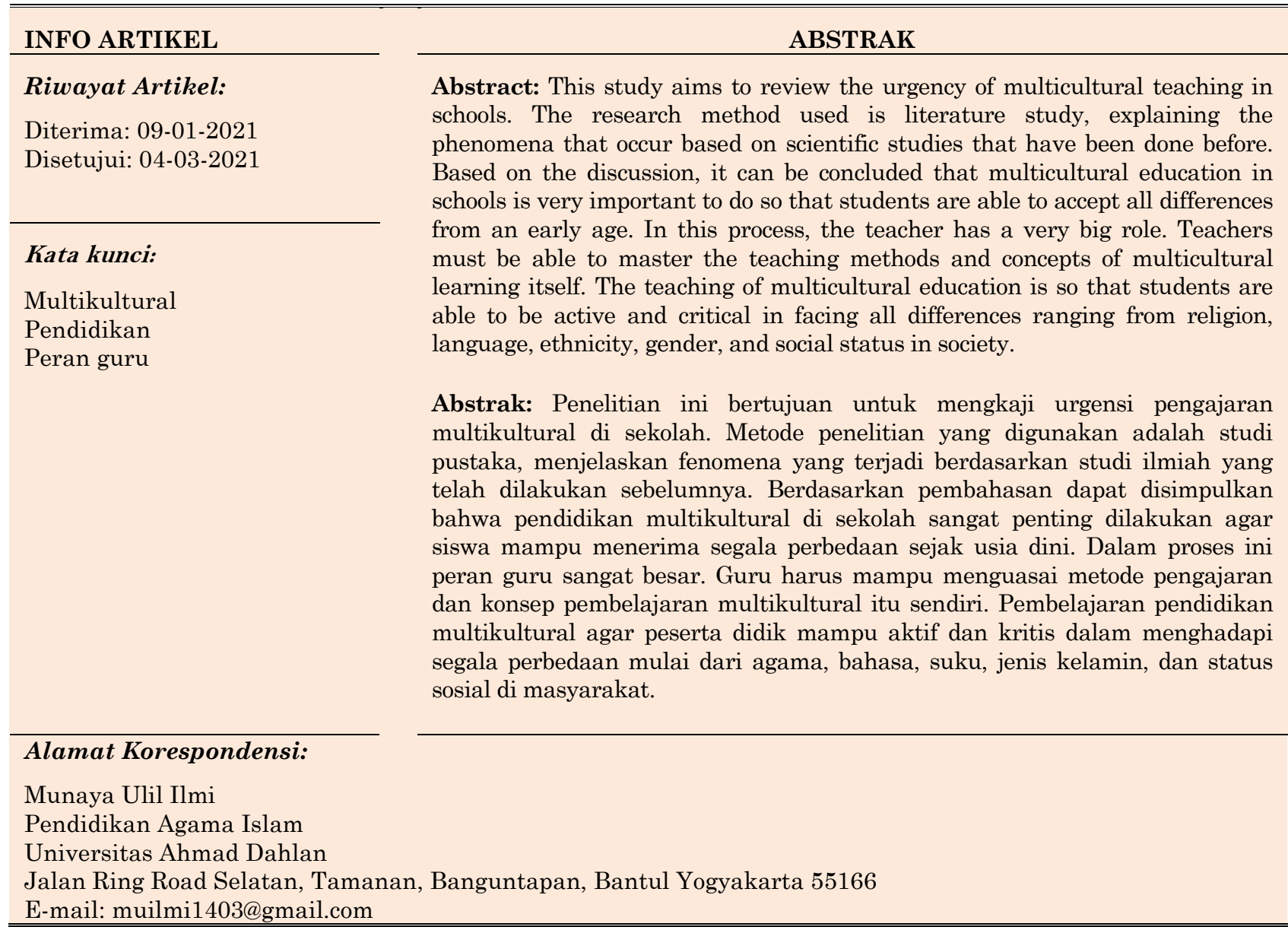

\section{PENDAHULUAN}

Indonesia merupakan negara yang terdiri dari berbagai pulau, suku, bahasa, budaya yang sangat beraneka ragam. Negara kepulauan adalah sebutan untuk Indonesia yang memiliki 13.000 pulau, 300 suku bangsa, dan 200 bahasa (Nurcahyono, 2018). Sedangkan agama yang dianut oleh masyarakat Indonesia terdapat 6 agama (Islam, Hindu, Budha, Kristen, Katolik, dan Konghuchu). Perbedaan tersebut menjadi bukti kekayaan dan terkadang masih sering menjadi sebab adanya perpecahan di Indonesia (Lestari, 2015). Untuk itu pengelolaan keberagaman perlu kita jaga dan tingkatkan guna menjaga kesatuan dan persatuan negara Indonesia. Rasa bangga terhadap perbedaan ini harus ditanamkan sejak dini agar mengakar dan mendarah daging pada masyarakat Indonesia.

Konflik antar etnis seperti pada etnis Dayak dan Madura di Salamantan Kalimantan Barat merupakan salah satu bukti dari belum tertanamnya semboyan negara kita Bhinneka Tunggal Ika di Indonesia. Jika konflik berbau SARA ini terus dibiarkan, maka akan memicu konflik yang serupa pada daerah lainnya. Untuk itu, konflik ini tidak bisa dianggap hal yang remeh dan perlu diatasi (Mahfud, 2016). Adanya budaya kekerasan di Indonesia didorong oleh empat faktor, yaitu: gagap akan budaya, ketidaksukaan dengan penganut agama lain, masyarakat 
indonesia yang intoleren, dan tidak berpihaknya politik kepada keadilan yang dilaksanakan oleh Orde Baru (Huda, 2005). Pemahaman yang kokoh diperlukan dalam mengurangi kemungkinan terjadinya konflik ini (Suparlan, 2002).

Multikultural berkaitan dengan permasalahan yang berhubungan dengan politik, sosial, demokrasi, HAM, dan permasalahan lainnya. Bukanlah hal yang mudah dalam membangun kesadaran untuk hidup dalam perbedaan, dibutuhkan usaha yang serius dan terus-menerus. Sikap multikulturalisme perlu ditanamkan. Tidak hanya menyadari akan banyaknya perbedaan. Akan tetapi, juga mendorong setiap individu untuk dapat berkontribusi dan saling membantu dalam kehidupan bersama. Salah satu cara untuk mengajarkan sikap multikulturalisme adalah melalui pendidikan.

Sekolah sebagai sumber belajar utama bagi pemuda bangsa sudah seharusnya berperan dalam pemahaman yang kokoh dan mendasar terkait kehidupan bersama dalam kultur yang berbeda atau yang biasa kita sebut dengan kata multikultural. Melalui pendidikan, guru mulai mengenalkan adanya keberagaman kultur Indonesia dengan lebih mendasar sebagai usaha untuk mencegah adanya konflik. Pengkajian mengenai peran guru dalam menciptakan kesadaran akan adanya keragaman dan kebhinekaan merupakan hal yang penting. Berdasarkan pemaparan di atas, maka tujuan penelitian ini adalah untuk mengetahui peran guru dalam pengajaran pendidikan multikultural. Penelitian ini merupakan penelitian kepustakaan (library research), yaitu penelitian yang dilakukan dengan menghimpun data dari berbagai literatur dalam pengumpulan datanya. Literatur yang diteliti tidak hanya berasal dari buku, melainkan dapat juga dari majalah, jurnal, maupun surat kabar

\section{METODE}

Penelitian ini merupakan analisis pustaka dengan tinjauan pustaka. Pengumpulan data dilakukan melalui penelusuran literatur ilmiah secara sistematis pada artikel-artikel jurnal dan dokumen yang membahasa secara signifikan dan berkaitan dengan tema penelitian ini. Konteks yang menjadi objek penelitian ini adalah studi kasus di Indonesia, maka data-data yang dielaborasi sangat berkaitan erat pada bagaimana peran guru dalam pengajaran pendidikan multikultural dapat dianalisis secara mendalam. Selanjutnya setelah dilakukan proses pengumpulan data dan analisis, maka peneliti memberikan kesimpulan akhir sebagai penutup hasil penelitian ini.

HASIL \& PEMIBAHASAN

\section{Pendidikan Multikultural di Sekolah}

Pendidikan multikultural terdiri dari dua kata yakni pendidikan dan multikultural. Pendidikan merupakan sebuah proses mengubah pilaku dan sikap dari sekelompok orang dan individu untuk memiliki pribadi yang lebih dewasa dengan mellaui, pelatihan, pengajaran, dan cara-cara mendidik. Sedangkan multikultural merupakan pembelajaran yang berdasarkan atas nilai-nilai budaya untuk mencapai sebuah pendidikan yang sama dan menghilangkan segala bentuk dari sebuah penindasan. Jadi pendidikan multikultural adalah sebuah proses mengubah prilaku dan sifat agar menjadi prbadi yang lebih dewasa dan membentuk sebuah keragaman budaya yang baik tanpa adanya sebuah penindasan. Pendidikan multikultural memandang kehidupan masyarakat dengan lebih luas dan juga wawasan yang luas. Pendidikan multkultural (Munadlir, 2016) mengajarkan kepada kita bahwa tidak ada perbedaan derajat semua manusia itu sama walapun kita berbeda ras, budaya, etnis, agama, dan berbeda dalam berendapat.

Pentingnya mengenalkan pendidikan multicultural (Hanum \& Rahmadonna, 2009) kepada peserta didik sejak dini agar mereka dapat memahami bahwa di lingkungan mereka dan di tempat lain memiliki keragaman yang berbeda-beda. Sekolah dasar perlu menanamkan nilai-nilai pendidikan multikuktural kepada peserta didik. Di sekolah dasar merupakan pondasi awal peserta didik dalam mengenal mengenai multikultural. Dengan menanamkan pendidikan multikultural sejak dini maka peserta didik akan memiliki pemahaman mengenai banyaknya keragaman yang ada di Indonesia. Tidak perlu sampai mengubah kurikulum pendidikan multikultural dapat di intergrasikan dengan pelajaran yang lain seperti pelajaran IPS. Dengan memberikan modul pembelajaran kepada peserta didik guna untuk menambah pengetahuan mereka dalam mempelajari pendidikan multikultural. Dengan model pembelajaran yang mampu diterapkan guru agar dapat diterapkan kepada peserta didik. Peserta didik perlu di terapkan tentang makna HAM, toleransi dan bagaimana cara mengharga adanya perbedaan. 
Menerapkan pendidikan multikultural di sekolah dasar dapat di laksanakan dengan memberikan mata pelajaran mengenai multikultural.

Dalam proses belajar mengajar strategi pembelajaran merupakan (Munadlir, 2016) hal yang perlu di kuasai oleh guru agar proses pembelajaran dapat berlangsung dengan baik. Strategi yang dapat dilakukan guru dalam mengenalkan pendidikan multikultural kepada peserta didik dengan melakukan proses diskusi. Hal ini dapat membuka awal pengetahuan mereka mengenai pendidikan multikultural. Dengan proses diskusi guru dapat memberikan informasi dan peserta didik dapat bertukar informasi dan pendapat dengan peserta didik lainnya. Dalam menjelaskan pemahaman mengenai multikultural juga perlu menggunakan bahasa yang mudah di pahami oleh peserta didik dan menggunakan metode yang menarik agar peserta didik merasa menyenangkan dalam mempelajarinya. Adanya pendidikan multikultural di sekolah dasar di harapkan agar peserta didik dapat mengetahui banyaknya keragaman yang ada di Indonesia.

\section{Konflik dan Problematika Dampak dari Perbedaan di Sekolah}

Kata konflik bermula dari kata confligere, conflictuan yakni memiliki arti saling berbenturan, yaitu semua bentuk benturan, tabrakan, ketidak sesuaian, pertentangan, perkelahian, dan oposisi serta interaksi yang antagonistis pertentangan (Nasution, 2010). Menurut Mangkunegara konflik merupakan sesuatu hal antara apa yang di harapkan oleh seseorang terhadap dirinya, orang lain, serta organisasi namun terdapat suatu pertentangan dengan apa yang diharapkannya (Mangkunegara, 2005). Adapun menurut Kreither dan Kinicki, ia mengemukakan konflik proses yakni dimana konflik itu bisa terjadi apabila satu pihak atau kelompok melihat pihak lain atau kelompok lain memiliki sikap negatif atau sikap yang berbeda mengenai hal-hal yang dipedulikan atau kata lain dari konflik proses merupakan konflik yang bisa terjadi apabila satu pihak yang dimaui oleh pihak lain merasa itu disikapi negatif atau ditentang oleh pihak lain (Nasution, 2010). Schnild and Scochan dikutip Kenneth dan Yukl bahwa konflik merupakan perselisihan antara dua orang pihak dengan ditandai menunjukkan permusuhan secara terbuka dan atau dengan sengaja mengganggu pencapaian tujuan yang menjadi lawannya (Kenneth \& Gary, 2003).

Dari beberapa pengertian konflik di atas terdapat kesamaan pengertian yaitu konflik berkaitan dengan sikap saling beroposisi , halangan dan asumsi dua pihak atau lebih yang berkepentingan atau tujuan yang tidak cocok yang terjadi diakibatkan oleh beberapa hal yakni: 1) perbedaan penafsiran ide; 2) sumber daya yang langka; 3) sasaran dan tujuaan yang ingin dicapai tidak sesuai,dll. Dalam konteks Indonesia, telah diasumsikan bahwa peserta didik di Indonesia ini terdiri dari latar belakang etnik yang beragam, agama, budaya, dan bahasa yang berbagai macam keragaman dari berbagai lembaga pendidikan di wilayah Indonesia ini. Indonesia mewarisi kemajemukan suku, ras, dan agama dengan perkembangan sejarahnya masing-masing. Hal ini diprediksikan pada data bahwa Indonesia memiliki latar belakang peserta didik yang beragam di berbagai sekolah di Indonesia juga bisa ditemui bahwa terdapat keragaman pada paham keagamaan, afiliasi politik, tingkat sosial ekonomi, adat istiadat, jenis kelamin dan asal daerah (perkotaan atau pedesaan). Indonesia yang merupakan negara bangsa yang terdiri atas etnis, agama dan bahasa yang beragam. Adapun permasalahan perbedaan yang dapat mengakibatkan konflik di sekolah, diantaranya:

\section{Masalah lingkungan yang tidak kondusif}

Globalisalisasi secara langsung atau tidak langsung dalam dunia pendidikan sangat jelas pengaruhnya dalam lingkungan sekolah (secara khusus) sebagai bagian dari sistem sosial. Sebagai akses globalisasi kegiatan dan aktivitas sekolah yang melingkupi telah menggeser lingkungan sekolah menjadi tidak kondusif lagi untuk iklim pembelajaran (Tholani, 2013).

Dari aspek pemikiran, sekolah atau perguruan tinggi dalam hal ini pendidikan sudah memiliki anggapan lain lagi, sekolah yang dulu dianggap tempat mencari ilmu atau kegiatan akademik-ilmiah, akan tetapi saat ini dianggap memiliki sisi lain sebagai tempat kaum muda pembelajar yang merayakan status kelasnya atau pendidikan dalam pikiran mereka sudah tidak bisa memberikan solusi atas masalah keseharian mereka, hal ini juga dipertegas dengan kejadian dimana banyaknya suguhan tayangan-tayangan oleh media elektronik berupa tayangan sinetron yang jauh berbeda dengan latar belakang mayoritas masyarakat dalam hal kesuksesan hidup dengan tahapan pendidikan yang dilalui atau dalam hal ketidak-suksesan karena tingkat pendidikan yang diselesaikan (Tholani, 2013).

Dari aspek perencanaan, proses pembelajaran yang dipraktekkan oleh sebagian pendidik seringkali monoton dan membosankan bagi peserta didik, sebab pendidik kurang menguasai skillnya untuk menghadirkan 
pemahaman materi dengan media pembelajaran yang kurang menarik dan susah diserap oleh peserta didik sehingga tidak bisa memberi makna (meaningfull learning) pada pembelajar, menimbulkan kejenuhan oleh peserta didik. Hal ini terjadi karena pembelajaran yang dilakukan oleh pendidik yang bersangkutan kurang menguasai model-model pembelajaran yang menarik, variatif, kreatif, dan inovatif. Dari aspek moralitas hukum, kurang meratanya dalam penyelesaian sebuah masalah baik itu di dalam ranah lingkungan sekolahan maupun di lingkungan masyarakat. Dari aspek kebijakan, di lembaga pendidikan pemerintah menetapkan standar kelulusan dengan membebankan aspek kognitif untuk mencapai skor seperti dalam bidang studi yang di Ujian Nasional-kan saja, sehingga bidang studi yang tidak di Ujian Nasional-kan menjadi terabaikan seperti pelajaran agama yang notabene lebih penting perannya dalam memberikan nilai-nilai spiritual kepada peserta didik.

\section{Masalah mentalitas atau moralitas yang masih rendah}

Jika kita menilik lebih seksama lagi, pelaksanaan praktek pendidikan di negara kita masih meninggalkan jejak kesan yang menggambarkan bahwa pendidikan di Indonesia ini masih belum sempurna, belum sistematis, dan jauh dari tujuan pendidikan itu sendiri dimana usaha mengembangkan potensi diri atau bakat seorang pembelajar dan penanaman atau penerapan nilai-nilai moral spiritual sebagai filosofi pendidikan atau pembelajaran, dan pada akhirnya tidak bisa berjalan dengan baik dalam prakteknya. Sehingga apabila pembelajar tidak lagi mengaplikasikan outcome dan outputnya yang mempunyai kemampuan atau keahlian dalam berpikir dan social skill dengan kepekaan nurani yang berlandasakan moralitas, sense of humanity pendidikan dinilai gagal (Tholani, 2013).

\section{Masalah Marjinalisasi}

Kita bisa menemui kasus di sekolahan dalam permasalahan yang hampir semua sekolah mengalami permasalahan ini yakni marjinalisasi. Perbedaan lebih sulit untuk dinegosiasikan dan menjadi realita di sekolahsekolah dan dalam lingkungan masyarakat yang lebih luas yang tidak terhindarkan olehnya. Perbedaan ini mengakibatkan peminggiran/marjinalisasi serta pengelompokkan yang eksklusif dari bebarapa individu yang sesuai dengan apa yang mereka rasa atau bisa dikatakan sefrekuensi. Contohnya para siswa yang saling membentuk persekutuan berdasarkan pada kemiripan etnis, akademis, atau sosioekonomis, dan bahkan terdapat hal yang salah pada para guru yang lebih mendukung para siswa yang serupa dengan dirinya. Jadi dengan kata lain dari pihak guru juga terdapat trend untuk lebih mengelompokkan siswa yang sejalan dan memiliki pola yang sama dalam belajar.

\section{Urgensi Pendidikan Multikultural di Sekolah}

Adanya keberagaman yang kita miliki berpotensi terhadap perpecahan masyarakat Indonesia. Untuk meminimalisir perpecahan tersebut dibutuhkan pendidikan yang kokoh dalam penanaman nilai-nilai kebersamaan, kesatuan, toleransi, serta bisa menyesuaikan diri terhadap perubahan. Pendidikan di atas merupakan pendidikan multikultural yang mengajarkan tata cara hidup menghormati dan toleransi terhadap setiap perbedaan hidup di tengah masyarakat plural. Dengan pendidikan multikultural diharapkan tercipta keluwesan mental masyarakat ketika terjadi benturan konflik sosial.

Dilaksanakannya pendidikan multikultural di sekolah bertujuan untuk menciptakan manusia yang berbudaya, mengajarkan nilai-nilai bangsa, kemanusiaan, dan nilai kelompok etnis (Mahfud, 2016). Adapun prinsip-prinsip dalam pelaksanaan pendidikan multikultural harus didasarkan pada: 1) Banyaknya ragam budaya sebagai dasar penentuan filsafat; 2) Sebagai dasar dalam pengembangan komponen dalam kurikulum seperti proses, konten, tujuan, hinga evaluasi; 3) Dalam lingkungan pendidikan, budaya merupakan sumber sumber dan objek belajar; 4) Peran kurikulum yaitu menjadi media untuk mengembangkan kebudayaan daerah maupun nasional (Haningsih, 2005). Pendidikan multikultural bisa menjadi solusi bagi masalah kebhinekaan sehingga terbangun rasa nasionalisme di Indonesia pada era global ini (Tukiran, 2014).

Unsur keluhuran sebagai nilai budaya yang terkandung dalam multikultural merupakan hal yang harus dijunjung tinggi dan dikenalkan pada diri siswa sejak siswa masih berusia dini (Utama, 2013). Hal ini ditujukan supaya anak bisa memahami serta menerima segala perbedaan yang ada pada budaya serta berdampak bagi perbedaan cara (usage), kebiasaan (folkways), aturan (mores), dan adat istiadat (customs). Cara menghormati dalam kehidupan, rasa tulus, dan toleran akan didapatkan jika pendidikan multikultural ini dapat ditanamkan di tengah masyarakat plural (Supardi, 2014). Apabila hal ini terjadi maka terciptalah masyarakat yang hidup rukun serta harmonis. 
Tidak hanya untuk menjaga nilai di masyarakat, pendidikan di sekolah juga harus mengajarkan sikap kritis dala memecahkan masalah sosial yang timbul kepada siswa (Supardan, 2015). Dalam hal ini, peserta didik diajarkan untuk kritis dan aktif apabila ada hal yang bertentangan dengan nilai kemanusiaan, keagamaan, terutama masalah multikulturalisme. Indonesia telah masuk pada suatu fase, dimana teknologi informasi sangat berkembang pesat dalam segala aspek kehidupan. Termasuk di dalamnya aspek pendidikan (Rahman \& Nuryana, 2019).

\section{Peran Guru dalam Pengajaran Pendidikan Multikultural}

Media dan sarana merupakan bagian startegi dalam mengembangkan pendidikan multikultural menjadi lebih baik. Lembaga pendidikan tidak hanya mengedepankan akademik peserta didik saja melainkan juga mengembangkan pemahaman peserta didik mengenai budaya hal ini sangat berpengaruh ketika peserta didik sudah terjun di lingkungan masyarakat (Munadlir, 2016). Oleh karena itu, sekolah perlu memberikan materi mengenai kebudayaan agar peserta didik memilki pemahaman yang baik hal ini untuk mencegah perbuatan diskriminasi budaya antar masyarakat dengan mempelajari mengenai kebudayaan peserta didik akan lebih menghormati dan juga menghargai adanya sebuah perbedaan. Dalam hal ini Guru dan sekolah sangat berperan penting dalam membangun nailai-nilai kebudayaan kepada peserta didik.

Guru merupakan sosok terpenting dalam sistem pendidikan. Guru menjadi orang yang paling berpengaruh bagi peserta didik dalam proses belajar. Dalam mengajarkan pendidikan multikultural guru perlu memiliki metode dan juga pendekatan agar mengetahui konsep dari pendidikan multikultural. Menggunakan diskusi guru dapat memberikan pemahaman kepada peserta didik mengenai pendidikan multikultural dan menerima respon dari peserta didik megenai pemahaman mereka mengenai adanya perbedaan kebudayaan yang pernah mereka temukan.

Dengan diskusi seperti ini peserta didik dapat bertukar pikiran dengan peserta didik lainnya sehingga membuat mereka memiliki pemahaman yang lebih luas. Terdapat beberapa peran guru (Widiyono, 2018) dalam mengimplementasikan pendidikan multikultural di sekolah:

\section{Adanya perbedaan agama}

Guru harus mampu bersikap adil terhadap peserta didik tidak sikap diskriminasi terhadap peserta didik yang memiliki karakter yang berbeda-beda. Jika terdapat peserta didik yang memiliki keyakinan agama yang berbeda maka peran guru disini tidak menunjukkan adanya sikap diskriminasi, apabila hal ini terjadi maka akan menimbulkan sebuah permusuhan dengan peserta didik lainnya.

\section{Perbedaan bahasa}

Bahasa merupakan alat komunikasi untuk berinerasi dalam kehidupan sehari-hari. guru harus memiliki wawasan dan juga membangun kesadaran kepada peserta didik agar peserta didik memiliki wawasa yang luas agar dapat mengetahui bahwa keragaman di indonesia itu sangatlah banyak.

\section{Perbedaan gender}

Laki-laki dan perempuan itu sama, memilii hak dan juga kewajiban ang sama. Namun, perempuan lebih cenderung di pandang sebelah mata dibading laki-laki. Contoh, terkadang guru lebih cenderung perhatian kepada perempuan dibanding laki-laki. Padahal, seharusnya seorang guru harus memperlakukan semua peserta didik dengan hak dan kewajiban yang sama tanpa adanya perbedaan.

\section{Perbedaan status sosial.}

Di sekolah negeri beberapa siswa memiliki keyakinan yang berbeda-beda. Disinilah peran guru dan sekolah dalam menjaga toleransi agar tidak terjadi diskriminasi atau perbedaan agama.

\section{Perbedaan etnis}

Perbuatan etnis yang paling sering ditemui adalah di sekolah. Peserta didik melakukan perbuatan yang tidak baik atau membully teman nya yang memiliki etnis yang berbeda dengannya. Peran guru disini adalah dengan memberikan pengetahuan yang lebih luas mengenai tidak baik nya prilaku diskriminasi terhadap seseorang hal itu akan membuat mental seseorang menjadi tergangu. Guru menjadi teladan yang baik agar dapat menjadi contoh kepada peserta didiknya. 


\section{SIMIPULAN}

Indonesia merupakan negara yang terdiri dari ras, suku, agama, budaya, dan bahasa yang sangat beragam. Perbedaan ini bisa menjadi sesuatu yang patut dibanggakan dan bisa juga menjadi sumber perpecahan. Untuk itu pengelolaan keberagaman perlu kita jaga dan tingkatkan guna menjaga kesatuan dan persatuan negara Indonesia. Rasa bangga terhadap perbedaan ini harus ditanamkan sejak dini agar mengakar dan mendarah daging pada masyarakat Indonesia. Penanaman rasa toleransi dalam perbedaan ini dapat dilakukan melalui pendidikan di sekolah yang dilaksanakan oleh guru kepada siswa. Guru berperan dalam menjelaskan hingga menanamkan sikap kritis dalam menghadapi permasalahan yang berkaitan dengan perbedaan agama, bahasa, gender, etnis, serta status sosial. Bila hal ini terjadi dan berjalan dengan baik maka masyarakat Indonesia dapat hidup dengan nyaman, aman, dan harmonis serta bersatu dalam segala perbedaan.

\section{DAFTAR RUJUKAN}

Haningsih, S. (2005). Esensi pendidikan Islam ditinjau dari pendidikan multikultural. Jurnal Pendidikan Islam FIAI Jurusan Tarbiyah, XII(VIII), 9-27.

Hanum, F., \& Rahmadonna, S. (2009). Implementasi model pembelajaran multikultural di Sekolah Dasar Provinsi Daerah Istimewa Yogyakarta. Artikel Multikultural- Stranas, 2(1), 1-17.

Huda, N. (2005). Multikulturalisme dalam bayang-bayang historiografi resmi/nasional. Dalam Abu Azyumardi Azra et. al, Nilai-nilai pluralisme dalam Islam bingkai gagasan yang berserak (I). Nuansa.

Kenneth, N. W., \& Gary, A. Y. (2003). Perilaku organisasi dan psikologi personalia. Rineka Cipta.

Lestari, G. (2015). Bhinnekha Tunggal Ika: Khasanah multikultural indonesia di tengah kehidupan SARA. Jurnal Pendidikan Pancasila Dan Kewarganegaraan, 28(1), 31-37.

Mahfud, C. (2016). Pendidikan multikultural. Pustaka Pelajar.

Mangkunegara, A. P. (2005). Perilaku dan budaya organisasi. PT Refika Aditama.

Munadlir, A. (2016). Strategi sekolah dalam pendidikan multikultural. Jurnal Pendidikan Sekolah Dasar, 2(2), $114-130$.

Nasution, I. (2010). Manajemen konflik di sekolah. Visipena, 1(1), 45-55.

Nurcahyono, O. H. (2018). Pendidkan multikultural di Indonesia: Analisis sinkronis dan diakronis. Habitus: Jurnal Pendidikan, Sosiologi Dan Antropologi, 2(1), 105-5.

Rahman, A., \& Nuryana, Z. (2019). Pendidikan Islam di Era Revolusi Industri 4.0. Kimojoyo Press.

Supardan, S. (2015). Pembelajaran ilmu pengetahuan sosial: Perspektif filosofi dan kurikulum. PT. Bumi Aksara.

Supardi, S. (2014). Pendidikan multikultural dalam pembelajaran sejarah lokal. Jurnal Pembangunan Pendidikan: Fondasi Dan Aplikasi, 2(1), 91-98.

Suparlan, P. (2002). Kesetaraan warga dan hak budaya komuniti dalam masyarakat majemuk Indonesia. Jurnal Antropologi Indonesia, 2(6), 1-12.

Tholani, M. I. (2013). Problematika pendidikan di Indonesia (Telaah Aspek Budaya). Jurnal Pendidikan, 1(2), 64-74.

Tukiran, T. (2014). Pendidikan multikultural dan nasionalisme di Indonesia. Jurnal Sosio Didaktika, 1(1), $29-36$.

Utama, E. J. P. (2013). Materi Sejarah dalam buku teks muatan lokal pendidikan multikultur Kalimantan Barat. Jurnal Socia: Jurnal Ilmu-Ilmu Sosial, 10(2), 157-166.

Widiyono, S. (2018). Peran guru dalam mengimplementasikan pendidikan multikultural. Elementary School: Jurnal Pendidikan Dan Pembelajaran Ke-SD-An, 5(2), 287-295. 